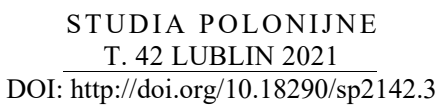

MICHAŁ KŁAKUS

\title{
„REGULAMIN DLA KAPELANÓW POLSKICH” WE FRANCJI - OKOLICZNOŚCI POWSTANIA
}

Historycy zajmujący się dziejami duszpasterstwa polskiego we Francji są zgodni, że podstawowym dokumentem, w którym określono podstawę prawną działalności polskich duszpasterzy w tym kraju w latach $1925-1952^{1}$, był „Règlement des Aumôniers Polonais” („Regulamin dla kapelanów polskich”) 2 . Zawierał on normy, wedle których winna być zorganizowana opieka duszpasterska nad polskimi wychodźcami, jak również poruszał sprawy dotyczące zabezpieczenia materialnego polskich kapelanów. W dokumencie tym starano się również uregulować stosunek do miejscowych biskupów i francuskich proboszczów. Jak wynika z tytułu „Regulaminu”, ${ }^{3}$, za jego redakcję mieli odpowiadać arcybiskup Paryża, kard. Louis-Ernest Dubois ${ }^{4}$ oraz sekretarz

Ks. dr MichaŁ KŁAKuS - proboszcz parafii św. Wiktora w Trans en Provense; Institut Diocésain de Formation Pastorale - Tulon, Francja; e-mail: mklakus@gmail.com. ORCID: https:// orcid.org/0000-0002-0012-7525.

${ }^{1}$ Ogłoszenie konstytucji Exsul Familia Piusa XII.

${ }^{2}$ R. Dzwonkowski, Polska opieka religijna we Francji 1909-1939, Poznań-Warszawa 1988, s. 59; B. PANEK, Księża polscy w duszpasterstwie pótnocnej Francji 1922-1929 (Materiały do dziejów Polskiej Misji Katolickiej we Francji, z. IV), Paris 1994, s. 15; G. GARÇON, Les catholiques polonais en France (1919-1949), Lille 2004; M. BRUDZISZ, Pierwsze zebranie księży Polskiej Misji Katolickiej we Francji, „Studia Polonijne” 33 (2012), s. 143-144; M. BrudzISZ, Archiwum Polskiej Misji Katolickiej we Francji, Kraków-Lublin 2015, s. 32; J. SZYMAŃSKI, „,Nie chcemy tego ukrywać” - oczami świadków. Sytuacja duszpasterstwa polonijnego w pótnocnej Francji w 1928 roku, „Archiwa, Biblioteki i Muzea Kościelne” 2012, t. 98, s. 407; K.M. ŻABA, Charakter życia religijnego Polonii a status prawny polonijnych instytucji religijnych we Francji, „Przegląd Polonijny” 13 (1987), nr 1, s. 54.

${ }^{3}$ Oficjalna nazwa dokumentu: Règlement des aumôniers polonais, établi entre le Cardinal Dubois Archevêque de Paris, assisté de Mgr Chollet et entre l'Episcopat Polonais, représenté par le Recteur de la Mission Polonaise Catholique, le Rév. Père Szymbor Guillaume (1924), patrz: Archiwum Kościoła i Hospicjum Świętego Stanisława w Rzymie, Archiwum biskupa Józefa Gawliny, sygn. AJG 1.

${ }^{4}$ Luis-Ernest Dubois (1856-1929) - biskup Verdun (1901), arcybiskup Bourges (1909), arcybiskup Rouen (1916) i arcybiskup Paryża (1920), kardynał (1916), Dictionnaire des évêques de France au $X X^{e}$ siècle, red. D.-M. Dauzet, F. Le Moigne [dalej: Dictionnaire], Paris 2010, s. 215-217. 
Komisji Stałej Zgromadzenia Kardynałów i Arcybiskupów a zarazem ordynariusz diecezji zamieszkanej przez liczną mniejszość polską, abp Jean-Arthur Chollet $^{5}$ z Cambrai, oraz Episkopat Polski ${ }^{6}$ reprezentowany przez Rektora Polskiej Misji w Paryżu, ks. Wilhelma Szymbora ${ }^{7}$. Redakcja tego dokumentu miała mieć miejsce w $1924 \mathrm{r}$.

R. Dzwonkowski i G. Garçon twierdzą, iż dokument ten podpisano w 1924 r., lecz zwlekano z jego ogłoszeniem do stycznia 1925 r. K.M. Żaba sugeruje w swoim artykule (jednak nie posiłkując się materiałami źródłowymi), że choć zredagowano go w 1924 r., to „podpisano ostatecznie w styczniu roku 1925”. M. Brudzisz (przywołując opracowanie G. Garçona) w artykule z 2012 r. w ogóle nie podał daty ogłoszenia dokumentu, zaznaczając jedynie, że ,właściwy Statut został opracowany przez obydwie strony w 1924 r. i ogłoszony" ${ }^{\prime 8}$, natomiast we wstępie do inwentarza Polskiej Misji Katolickiej z 2015 r. pisał, iż został on dopracowany i podpisany w 1924 r., ale ogłoszony w 1925 r. ${ }^{9}$ J. Szymański wskazywał, że „Règlement” został ostatecznie opracowany i ogłoszony w $1924 \mathrm{r}$.

Jeżeli dokument ten miał być podpisany w 1924 r., a ogłoszony dopiero w 1925 r., to zasadne pozostaje pytanie o przyczynę tej zwłoki. Dlaczego tak ważnego dokumentu nie ogłoszono natychmiast? Czy wersja dokumentu przygotowanego w 1924 r. była tożsama z ogłoszonym w 1925 r.? A jeżeli nie, to kto nadał mu ostateczną formę? Odpowiedzi na te pytania można znaleźć analizując dokumenty zgromadzone w Narodowym Centrum Archiwów Kościoła we Francji (CNAEF). Materiały tam zdeponowane pozwalają również prześledzić proces powstawania tak ważnego dla organizacji duszpasterstwa polskiego we Francji dokumentu.

Po odzyskaniu niepodległości biskupi polscy podczas wszystkich sesji Episkopatu Polski poruszali problem organizacji duszpasterstwa dla emigrantów polskich. W czasie VIII sesji, która odbyła się 2 czerwca 1921 r.,

\footnotetext{
${ }^{5}$ Jean-Arthur Chollet (1862-1952) - biskup Verdun (1910), arcybiskup Cambrai (1913). Sekretarz Komisji Stałej Zgromadzenia Kardynałów i Arcybiskupów (ACA), Dictionnaire..., s. 154-155.

${ }^{6}$ W 1921 r. Episkopat Polski powierzył Prymasowi opiekę nad emigrantami polskimi w różnych krajach. Misja Polska we Francji miała charakter delegatury Prymasa Polski, patrz: J. GRUSZYŃSKI, Integracja religijna Polaków we Francji, „Studia Polonijne” 4 (1981), s. 161; J. BAKALARZ, Duszpasterstwo polonijne, [w:] Encyklopedia Katolicka, t. V, Lublin 1989, kol. 616-618.

${ }^{7}$ Ks. Wilhelm Szymbor CM (1879-1949) - ksiądz ze Zgromadzenia Misjonarzy św. Wincentego a Paulo (1903), Rektor PMK (1922-1929)

${ }^{8}$ M. BRUDZISZ, Pierwsze zebranie księży..., s. 143-144.

${ }^{9}$ M. Brudzisz, Archiwum Polskiej Misji..., s. 32.
} 
oficjalnie powierzyli opiekę nad wychodźstwem Prymasowi Polski ${ }^{10} .19$ czerwca 1922 r. kard. Edmund Dalbor ${ }^{11}$ oraz odpowiedzialny za duszpasterstwo cudzoziemców w diecezji paryskiej bp Emmanuel Chaptal ${ }^{12}$ zatwierdzili statut Polskiej Misji Katolickiej w Paryżu. Trzy miesiące później, 16 września ${ }^{13}$ ks. W. Szymbor przesłał jego kopię biskupom francuskim. W dokumencie tym pisano o nadrzędnej roli Rektora Polskiej Misji w sprawach organizacji duszpasterstwa polskiego we Francji wskazując, by rządcy diecezji kierowali do pracy duszpasterskiej wśród Polaków we Francji jedynie księży wskazanych przez niego. Ksiądz Szymbor prosił biskupów francuskich o ogłoszenie statutu w prasie diecezjalnej („Semaine religieuse”), jak również zwracał się o przesłanie na adres Misji Polskiej wykazu Polaków zamieszkujących poszczególne diecezje. Z pewnością jego pismo wywołało reakcję biskupów francuskich, którzy mogli odnieść wrażenie o próbach tworzenia niezależnej od ich władzy struktury kościelnej. Nieprzypadkowo więc 12 września 1923 r. kard. Dubois próbował rozwiać ich wątpliwości. W skierowanym do nich liście władze diecezji paryskiej informowały o podległości Rektora Polskiej Misji Katolickiej względem ks. bpa E. Chaptala. Do zadań ks. Szymbora miała należeć kontrola polskich duszpasterzy, zaś o organizacji duszpasterstwa na terenie Francji i przydziale polskich księży miał (współ)decydować biskup odpowiedzialny za duszpasterstwo cudzoziemców w Paryżu ${ }^{14}$. Taki rozwój sytuacji musiał jednak zaniepokoić Prymasa Polski, zwłaszcza że został o nich oficjalnie poinformowany w listopadzie $1923 \mathrm{r} .{ }^{15} \mathrm{~W}$ liście do arcybiskupa gnieźnieńskiego i poznańskiego kard. Dubois tłumacząc, iż

${ }^{10}$ B. KoŁodzIEJ, Biskup polscy $w$ trosce o polskich emigrantów, „Studia Prymasowskie” 2 (2008), s. 207.

${ }^{11}$ Edmund Dalbor (1869-1926) - arcybiskup metropolita gnieźnieński i poznański, Prymas Polski (1915), kardynał (1919).

${ }^{12}$ Emmanuel (Anatole) Chaptal de Chanteloup (1861-1943) - biskup pomocniczy Paryża (1922), tyt. Isionda. Ojciec był Francuzem a matka Żydówką (ochrzczoną) pochodzenia rosyjskiego. Przed wstąpieniem do seminarium pracował w służbach dyplomatycznych w Sztokholmie, St. Petersburgu, Konstantynopolu i Monachium. W 1897 r. przyjął święcenia kapłańskie. W pracy duszpasterskiej szczególnie poświęcił się służbie na rzecz chorych i ubogich. Zdyscyplinowany, o przyjemnym usposobieniu. Odpowiedzialny za sprawy organizacji duszpasterstwa obcokrajowców w Paryżu, Dictionnaire..., s. 141-142.

${ }^{13}$ R. Dzwonkowski pisał, że przesłano „pod koniec czerwca 1922”, jednak dokument został podpisany i wysłany 16 IX 1922 przez ks. Szymbora, patrz: Le Centre national des archives de l'Église de France, Service national pour la pastorale des migrants [SNPM], sygn. $121 \mathrm{CO} 1$ [dalej: CNAEF], Statut de la Mission Polonaise à Paris, Poznan, 19 VI 1922; R. Dzwonkowski, Polska opieka religijna..., s. 59.

${ }^{14}$ CNAEF, Dubois do Monseignieur, Paris, 12 X 1923; Chaptal do Monseignieur, Paris, 12 X 1923.

${ }^{15}$ Archives historiques du diocèse de Paris [dalej: AHP], Louis-Ernest Dubois, sygn. 1D 12, 14, Dubois do Dalbora, Paris, 11 XI 1923. 
w sprawach opieki religijnej nad Polakami konieczne będzie nawiązywanie relacji z francuskimi instytucjami kościelnymi i świeckimi, mianował bpa Chaptala przełożonym Rektora Polskiej Misji, który miał być informowany o wszystkich zamierzeniach episkopatu Polski w sprawach dotyczących organizacji duszpasterstwa w całej Francji. Co więcej, arcybiskup Paryża swego sufragana (a nie Prymasa Polski) uważał za „centrum i inspiratora Misji Polskiej w Paryżu" ${ }^{\prime 6}$. List z Paryża spotkał się ze stanowczą reakcją kard. Dalbora. W liście z 10 grudnia 1922 r. jako nieporozumienie odebrał próbę narzucenia Polskiej Misji Katolickiej kontroli ze strony władz diecezji paryskiej. Podawał on w wątpliwość jurysdykcję bpa Chaptala nad katolickimi cudzoziemcami na terenie całego kraju, przypominając, iż są one ograniczone (odmiennie niż Rektora PMK) jedynie do diecezji paryskiej. Tym samym przypominał kard. Dubois, iż ks. Szymbor był odpowiedzialny za duszpasterstwo polskie ${ }^{17}$. Niepokój Prymasa Polski wzbudziła również inna propozycja zawarta w liście kard. Dubois, a zobowiązująca dzieci z polskich rodzin „w wieku 13 lat i powyżej” do uczęszczania na katechizm w j. francuskim. Prymas uznał ją, z powodu nieznajomości języka w środowisku całkowicie obcym, za niemożliwą do realizacji ${ }^{18}$.

Powyższe fakty świadczyły, że już kilka miesięcy po podpisaniu zaistniała potrzeba opracowania szczegółowego dokumentu, w którym zostałyby sprecyzowane zasady organizacji duszpasterstwa polskiego we Francji. Zwłaszcza że biskupi francuscy, na terenie diecezji których istniały kolonie polskie, zaczęli tworzyć własne przepisy określające zasady prowadzenia duszpasterstwa dla Polaków. W styczniu 1923 r. bp Eugène Julien ${ }^{19}$ z diecezji Arras wydał zasady dla polskich duszpasterzy, w których byli oni pozbawieni jakiejkolwiek samodzielności i zmuszeni okazywać bezwzględne posłuszeństwo biskupowi miejsca, któremu przysługiwało prawo określania zakresu ich pracy duszpasterskiej ${ }^{20}$. Prymasowi Polski zależało więc na wypracowaniu

16 „Monseigneur Chaptal a travaillé de tout son pouvoir à faciliter la tâche de la mission Polonaise. Il a quelquefois à vaincre des difficultés qui proviennent de la diversité des institutions religieuses, ecclésiastiques ou civiles, que rencontre la Mission Polonaises dans l'accomplissement de sa mission sur le territoire français. Il est important qu'étant responsable de la direction spirituelle de cette Mission, c'est à lui que soient données les communications de l'Episcopat polonais qui peuvent se rapporter à cette direction, et qu'il soit véritablement le centre et l'inspirateur de cette Mission en France", CNAEF, Dubois do Dalbora, Paris, 11 XI 1923.

${ }^{17}$ CNAEF, Dalbor do Dubois, Poznań, 10 XII 1922.

${ }^{18}$ Tamże.

${ }^{19}$ Eugène Julien (1856-1930) - biskup Arras (1917), Dictionnaire..., s. 362-263.

${ }^{20}$ AHP, Polonais, sygn. 9K2 3, Evêché d'Arras, Organisation du service religieux en faveur des Polonais dans la region houllières, Arras, 8 I 1923. Podobne zarządzenie obowiązywało 
jednolitych i obowiązujących w całej Francji zasad organizacji duszpasterstwa polskiego w tym kraju $\mathrm{z}$ uwzględnieniem swoistości religijności polskiej. W jego opinii należało najpierw zapoznać biskupów francuskich ze specyfiką polskiego duszpasterstwa, zwyczajami i tradycjami, którymi żyli wierni w Polsce. Już 16 lutego 1923 r. (czyli miesiąc po podpisaniu „Regulaminu z Arras") nakazał on Rektorowi Misji Polskiej zbadać w kurii w Paryżu reakcję na propozycję zaproszenia biskupów francuskich do Polski. Doszło do niej w czerwcu 1924 r. $^{21}$ Biskupi francuscy byli pod wrażeniem sposobu organizacji duszpasterstwa w II Rzeczypospolitej ${ }^{22}$.

W czasie trwania wizyty podjęto również próby ustalenia „Regulaminu dla kapelanów polskich", lecz bez powzięcia ostatecznych rozwiązań. Pertraktacje między kard. Dalborem a bpem Chaptalem trwały jeszcze po powrocie biskupów francuskich z Polski. Ustalono prawo nauczania katechizmu w j. polskim dla dzieci w wieku od 7 do 13 r. życia. Na dwa lata określono okres przygotowań do Pierwszej Komunii św. Prymas Polski zgodził się, by $\mathrm{w}$ przypadku braku księży polskich nauka religii była prowadzona $\mathrm{w}$ j. francuskim przez miejscowych duszpasterzy, zaś w przypadku sporów próby mediacji podejmowali, po uzyskaniu zgody biskupów miejsca, ks. W. Szymbor oraz bp E. Chaptal ${ }^{23}$. Celem zapoznania się z problemami duszpasterstwa polskiego we Francji, wyjaśnieniem nieporozumień i ułatwieniem pracy polskich duszpasterzy bp Chaptal zaproponował przeprowadzenie wizytacji kolonii polskich we Francji ${ }^{24}$. Propozycja ta spotkała się z poparciem kard. Dalbora, „który nie wątpił w pełny sukces tej ankiety” z zastrzeżeniem, by mógł w niej wziąć udział Rektor Polskiej Misji dając świadectwo, że odbywają się one za wiedzą i poparciem polskich biskupów ${ }^{25}$. Jak tłumaczył arcybiskup gnieźnieński i poznański, obecność ta była niezbędna, ponieważ polscy emigranci, którzy przybyli z Westfalii, byli zmuszeni bronić prawa używania języka ojczystego w czasie nabożeństw, gdyż spotykali się z próbami germanizacyjnymi ze strony duchowieństwa niemieckiego. Zachęcał więc bpa Chaptala

prawdopodobnie od marca 1923 r. w diecezji Cambrai, patrz: tamże, Service religieux des Polonais dans le diocèse de Cambrai, Cambrai, marzec [?] 1923; B. PANEK, Księża polscy..., s. 32.

${ }^{21}$ Prócz arcybiskupa Paryża w wyjeździe do Polski udział wzięli: kard. Baudrillart (1859-1942), abp Chollet z Cambrai, bp Julien z Arras, bp E. Chaptal, wikariusz generalny diecezji paryskiej, ks. Delabar (1867-1937) oraz ks. W. Szymbor.

${ }^{22}$ Więcej na ten temat: M. KLAKus, Visite des évêques français en Pologne en 1924 à la lumière de dossier déposé par le Cardinal Dubois dans les archives historiques du diocèse de Paris, „Archiwa, Biblioteki i Muzea Kościelne” 2020, t. 113, s. 221-235.

${ }^{23}$ CNAEF, Les prêtres étudiants, Paris, [b.d.].

${ }^{24}$ CNAEF, Chaptal do Dalbora, Paris, 30 X 1924.

${ }^{25}$ CNAEF, Dalbor do Chaptala, Poznań, 9 XI 1924. 
do wsłuchiwania się w potrzeby duchowe polskich emigrantów ${ }^{26}$. W rzeczywistości, pod koniec 1924 r. miały miejsce wspomniane wizytacje polskich kolonii w regionie Nord i Pas-de-Calais. W czasie spotkań z rodzinami polskich robotników bp Chaptal zapewnil, iż w sprawach organizacji duszpasterstwa na pierwszym miejscu będzie brane pod uwagę dobro polskich rodzin $^{27}$. Sprawą sporną były prawa do tzw. casuel, czyli ofiar składanych przy okazji chrztów, ślubów czy pogrzebów. Biskup pomocniczy diecezji paryskiej proponował, aby polscy księża zrezygnowali z prawa do tych ofiar, a całość przekazywali francuskiemu proboszczowi. Miało to zapobiec ewentualnym konfliktom między proboszczami francuskimi i polskimi kapelanami ${ }^{28}$. W odpowiedzi na tę propozycję Prymas Polski przewidywał, że jej zaakceptowanie prowadziłoby do zubożenia polskich księży i wymagałoby zgody władz kopalni, które wspomagały finansowo polskich duszpasterzy, na podniesienie ich uposażeń ${ }^{29}$.

16 grudnia 1924 r. w siedzibie biskupów paryskich miało miejsce spotkanie, na którym planowano zebrać propozycje, które służyłyby za podstawę do przygotowania „Regulaminu” ${ }^{30}$. Na spotkanie, prócz delegacji polskich księży pod przewodnictwem ks. W. Szymbora, zostali zaproszeni biskupi francuscy. $\mathrm{Ci}$ jednak nie wykazali zbytniego zainteresowania. Pierre-Célestin Cézérac ${ }^{31} \mathrm{z}$ Albi oraz Jean-Baptiste Pelt ${ }^{32} \mathrm{z}$ Metz poinformowali o niemożności przybycia na zebranie, udzielając jednocześnie poparcia dla (ewentualnie) podjętych w czasie spotkania decyzji. W spotkaniu nie mógł również wziąć udziału Charles Gibier ${ }^{33}$ z Versailles, lecz prosił bpa Chaptala o przesłanie powziętych rozwiązań celem zbadania ich użyteczności na terenie swojej diecezji. Swoją nieobecność zgłosili również biskupi z Autun ${ }^{34}$, Arras, Meaux $^{35}$ i Lyonu $^{36}$. Kardynał Louis-Joseph Maurin (Lyon) wyraził nadzieję,

26 Tamże.

${ }^{27}$ CNAEF, Pour la Reunion du 27 janvier 1925, Paris [b.d.].

${ }^{28}$ CNAEF, Chaptal do Dalbora, Paris, 30 X 1924.

${ }^{29}$ CNAEF, Dalbor do Chaptala, Poznań, 9 XI 1924.

${ }^{30}$ CNAEF, Règlement proposé par S.G. Mgr Chaptal, Paris, [b.d.]. R. Dzwonkowski dysponując jedynie załącznikiem podpisanym przez bpa Chaptala (ale bez daty) błędnie wnioskował, iż zebranie to miało miejsce w grudniu 1923 r., R. Dzwonkowski, Polska opieka religijna..., s. 59.

${ }^{31}$ Pierre-Célestin Cézérac (1856-1940) - biskup Cahors (1911), arcybiskup Albi (1918), Dictionnaire..., s. 132-133.

32 Jean-Baptiste Pelt (1863-1937) - biskup Metzu (1919), Dictionnaire..., s. 517.

${ }^{33}$ Charles Gibier (1849-1931) - biskup Versailles (1906), Dictionnaire..., s. 297-298.

34 Hyacinthe Chassagnon (1964-1940) - biskup pomocniczy Lyonu (1917), biskup Autun (1922), Dictionnaire..., s. 145.

${ }^{35}$ Louis-Joseph Gaillard (1872-1956) - biskup Meaux (1921-1931), arcybiskup Tours (1931), Dictionnaire..., s. 280-281. 
że spotkanie to zakończy się powzięciem dobrych decyzji, które pomogą w koordynacji pracy duszpasterskiej księży polskich ${ }^{37}$. Nie wiemy, ilu z nich uczestniczyło $\mathrm{w}$ spotkaniu. Jednak $\mathrm{z}$ zachowanej $\mathrm{w}$ archiwum diecezji paryskiej notatki wynikało, że $\mathrm{z}$ pewnością obecny był (prócz Dubois i Chaptala) abp Chollet z Cambrai.

Spotkanie rozpoczęło się odczytaniem listu polskich księży. Pierwsza jego część miała wyraźnie charakter hołdowniczy. Polscy duszpasterze wyrazili podziękowania biskupom francuskim za umożliwienie im pracy duszpasterskiej we Francji. Podkreślili ojcowską opiekę, jakiej doświadczyli ze strony rządców tutejszych diecezji. Zapewniali o lojalności względem miejscowych ordynariuszy w sprawach dotyczących organizacji opieki duszpasterskiej nad Polakami. Przywołując niedawną wizytę biskupów francuskich w Polsce, przypominali o więzach braterstwa łączących oba narody, o wzajemnej miłości, szacunku i przywiązaniu. Podkreślili, iż w żadnym wypadku celem ich pracy duszpasterskiej nie będzie tworzenie niezależnych od francuskich polskich struktur kościelnych ani też kwestionowanie praw miejscowych proboszczów nad polskimi wiernymi. Mając na względzie jedność duchowieństwa niezależnie od narodowości, zwrócili się również do kard. Dubois o pomoc w przypadku nieporozumień i wzajemnych sporów.

Druga część listu była poświęcona sprawom organizacji duszpasterstwa polskiego we Francji oraz kwestiom uposażenia księży. Rektor Polskiej Misji Katolickiej sygnalizował problem zapewnienia polskiemu kapelanowi stałego (lub tymczasowego w przypadku duszpasterstwa „okrężnego”) miejsca zamieszkania przy kolonii polskiej. Wskazywano, że najlepszym rozwiązaniem byłoby, gdyby mógł on stale korzystać z gościny miejscowego proboszcza lub (o ile działa na terenie parafii) znaleźć lokum w klasztorze, lub umożliwić zamieszkanie u zaufanej rodziny. Miało to zapobiec konieczności poszukiwania noclegu w hotelach.

Kolejny punkt dotyczył udostępnienia na potrzeby duszpasterstwa polskiego miejscowych kościołów w dogodnych godzinach i z zapewnieniem odpowiedniego czasu na ich przeprowadzenie, a także umożliwienia polskiemu duszpasterzowi korzystania z konfesjonału, przy którym umieszczono by informację o możliwości spowiedzi w j. polskim. W czasie spotkania apelowano, aby księża francuscy nie odmawiali polskiemu kapelanowi zgody na

\footnotetext{
${ }^{36}$ Louis-Joseph Maurin (1859-1936) - biskup Grenoble (1911), arcybiskup Lyonu (1916), kardynał (1916), Dictionnaire..., s. 461-462.

${ }^{37}$ CNAEF, [Notatka - uczestnictwo biskupów francuskich w zebraniu z księżmi polskimi w Paryżu, Paryż, 16 XII 1924].
} 
chrzest dzieci polskich w przypadku nieznajomości przez rodziców dziecka j. francuskiego. $Z$ tego samego powodu nie sprzeciwiali się prowadzenia katechizacji przygotowującej do przyjęcia sakramentów spowiedzi i Pierwszej Komunii oraz przeprowadzenia samej uroczystości związanej z przyjęciem Ciała Pańskiego w języku ojczystym rodziców. Ksiądz W. Szymbor wyraził nadzieję, że biskupi francuscy udzielą polskim kapelanom jurysdykcji generalnej pozwalającej na udzielanie ślubu między osobami polskiego pochodzenia na terenie parafii ich zamieszkania. Prosił również, by na żądanie rodzin polskich umożliwiono księżom polskim przewodniczenie pogrzebom. Obecni na zebraniu przedstawiciele Polskiej Misji domagali się od francuskich hierarchów przywileju prowadzenia własnych ksiąg parafialnych, których kopie co roku byłyby sporządzane do kurii diecezjalnych, oraz prawa do ofiar (casuel) z okazji sprawowanych przez nich sakramentów i pogrzebów Polaków. Ofiary zbierane w czasie polskich nabożeństw odprawianych we francuskich kościołach miały być dzielone na dwie części, z których jedna służyłaby na pokrycie kosztów korzystania ze świątyni, a druga na potrzeby duszpasterstwa polskiego ${ }^{38}$.

Owocem spotkania było przygotowanie przez bpa E. Chaptala „Projektu regulaminu dla kapelanów polskich we Francji”" ${ }^{39}$. Składał się on z dziesięciu punktów. Uwzględniono w nim większość propozycji zgłaszanych przez księży polskich w czasie grudniowego spotkania. Różnice dotyczyły m.in. miejsca zamieszkania księży polskich ${ }^{40}$, godzin udostępniania kościoła parafialnego na rzecz nabożeństw polskich ${ }^{41}$. W sprawie prowadzenia ksiąg parafialnych w projekcie zapisano konieczność odnotowywania przyjęcia sakramentów (lub sprawowanych pogrzebów) dla Polaków w księgach parafialnych, dopuszczając jedynie możliwość prowadzenia dodatkowych ksiąg metrykalnych jedynie do użytku prywatnego polskiego duszpasterza. Była to zmiana istotna, gdyż w myśl propozycji ks. W. Szymbora to polscy duszpasterze (lub ewentualnie władze kurialne, gdzie znajdowały się kopie ksiąg) mieliby prawo do wystawiania zaświadczeń o przyjętych sakramentach, zaś w zamyśle bpa Chaptala prawo to przysługiwało francuskim proboszczom. W przygotowanym projekcie znalazła się propozycja utworzenia niższego seminarium dla chłopców

\footnotetext{
${ }^{38}$ CNAEF, Eminance! Messegineurs!, Paris, [b.d.].

${ }^{39} \mathrm{CNAEF}$, Règlement proposé par S.G. Mgr Chaptal, Paris, [b.d.].

${ }^{40}$ Bp Chaptal proponował, by za ich miejsce zamieszkania odpowiadały ,administracje, na których prośbę przybywali do polskich kolonii lub proboszczowie".

${ }^{41} \mathrm{O}$ ile polscy księża proponowali, by było to możliwe w godzinach „dogodnych” dla polskich wiernych, o tyle bp Chaptal wspominał jedynie o godzinach „ustalonych z wyprzedzeniem z miejscowym proboszczem".
} 
z polskich rodzin. Za jego organizację odpowiedzialny byłby ordynariusz Paryża, a celem byłoby przygotowywanie kandydatów do seminariów duchownych dla zasilenia kadry polskich duszpasterzy we Francji. Również ta propozycja mogła budzić wątpliwości księży polskich, obawiających się nieznajomości przez jego wychowanków polskich zwyczajów i tradycji religijnych.

8 stycznia 1925 r. proponowany „Regulamin” został przesłany z prośbą o uwagi Prymasowi Polski, a dwa dni później, nie czekając na odpowiedź z Polski, rozesłano jego kopię biskupom francuskim ${ }^{42}$. Jak pisał kard. Dubois, propozycje przygotowane przez bpa Chaptala miały być „głównymi punktami, na podstawie których zgoda co do opracowania Regulaminu będzie możliwa do osiągnięcia"43. Jak wynika z przesyłanych do Paryża uwag co do „Projektu”, konsultacje trwały do marca 1925 r.

Biskupi z Rouen ${ }^{44}$ i Meaux zaakceptowali propozycję bpa Chaptala bez zastrzeżeń $^{45}$. Biskup z Varseilles, zapewniając o przestrzeganiu zasad zawartych w „Regulaminie”, wyznaczył jednocześnie jednego z wikariuszy generalnych odpowiedzialnym za sprawy duszpasterstwa polskiego w swojej diecezji ${ }^{46}$. Z zastrzeżeniami dokument ten został przyjęty w diecezji Beauvais. Biskup Eugène Le Senne ${ }^{47}$, tłumacząc się brakiem możliwości sprawowania kontroli nad księżmi polskimi pracującymi w duszpasterstwie okrężnym, sprzeciwił się nadaniu im prawa do udzielania dzieciom polskim sakramentu chrztu świętego. Sceptycznie wypowiedział się również o możliwości rezerwowania dla księży polskich konfesjonału w kościołach swojej diecezji, zwracając uwagę, że księża francuscy mogli spowiadać wiernych polskich korzystając z przygotowanego przez Polską Misję Katolicką podręcznika ${ }^{48}$ umożliwiającego sprawowanie tego sakramentu księżom nieznającym j. polskiego ${ }^{49}$.

Najwięcej uwag i zastrzeżeń do projektu „Règlement” złożyli biskupi z Arras i Cambrai, czyli z diecezji zamieszkiwanych przed najliczniejszą grupę

${ }^{42}$ CNAEF, Dubois do Monseigneur, Paris, 10 I 1925; Règlement proposé par S.G. Mgr Chaptal, Paris, [b.d.].

${ }^{43}$ Tamże.

${ }^{44}$ André-Pierre du Bois de La Villerabel (1864-1938) - biskup Amiens (1915-1920), arcybiskup Rouen (1920-1936), Dictionnaire..., s. 218-219.

${ }^{45}$ CNAEF, Du Bois de La Villerabel do Dubois, Rouen, 13 I 1925; Gaillard do Dubois, Meaux, 15 I 1925.

${ }^{46}$ CNAEF, Gibier do Dubois, Versailles, 23 I 1925.

${ }^{47}$ Eugène Le Senne (1866-1937) - biskup Beauvais, Nouon i Senlis, Dictionnaire..., s. 414-415.

48 „Confesseur Polonais ou Mèthode permettant à tout prêtre parlant le français de confesser des Polonais sans savoir leur langue".

${ }^{49}$ CNAEF, Le Senne do Dubois, Beauvais, 17 I 1925. 
polskiego wychodźstwa. Pomimo że wymieniali między sobą uwagi na ten temat, to w lutym 1925 r. przesłali dwa oddzielne pisma do bpa Chaptala $\mathrm{w}$ tej sprawie. Zastrzeżenia dotyczyły wszystkich proponowanych punktów regulaminu. Zależało im, by w przyszłym dokumencie uwydatnić rolę i znaczenie proboszcza miejsca (francuskiego) jako odpowiedzialnego za sprawy duszpasterstwa na terenie swojej parafii, przy jednoczesnym podkreśleniu braku tych uprawnień u księży polskich pozostających pod władzą tychże proboszczów. Odmawiano przyznania im prawa do posiadania delegacji generalnej co do sprawowania sakramentów, lecz za każdym razem będą musieli zwracać się o zgodę do miejscowego proboszcza. Miało to zapobiec w opinii biskupa z Arras tworzenia ,parafii w parafii”. Eugène Julien z Arras za niedopuszczalne uważał zamieszkanie księdza polskiego nie tylko w hotelach, ale również w domach prywatnych polskich rodzin. Odnośnie do sprawowania sakramentów obowiązywałoby ich prawo diecezjalne. Celem uzyskania zgody na sprawowanie sakramentu (chrztu, ślubu) czy pogrzebu w kościele parafialnym polski duszpasterz miał podać proboszczowi miejsca dokładne dane petenta. Podkreślano konieczność zapisu udzielonych sakramentów w księgach parafialnych. Nabożeństwa polskie kończyłyby się o ustalonych z proboszczem miejsca godzinach. Ofiary casuel miały być dzielone według norm diecezjalnych. Ofiary (w czasie ofiarowania) składane w czasie sprawowania sakramentów miałyby być przekazywane proboszczowi francuskiemu, z wyjątkiem innych dodatkowych ofiar, które mógł zatrzymać sobie polski duszpasterz. Kolekty zbierane w czasie mszy niedzielnych mogłyby być przeznaczane po połowie na rzecz utrzymania miejscowego kościoła i duszpasterstwa polskiego. Polski duszpasterz miał być zobowiązany do przeprowadzenia corocznej zbiórki na rzecz utrzymania duchowieństwa i przekazywać ją władzom diecezji, a także do corocznego sporządzania raportu z prowadzonej działalności duszpasterskiej wśród Polaków ${ }^{50}$.

Jak już wspomniano, z propozycją bpa Chaptala miał okazję zapoznać się również Prymas Polski. Odpowiedź z Poznania nadeszła 20 marca 1925 r. Kardynał Dalbor podziękował za przesłane w styczniu 1925 r. propozycje. Wnioskował, by polskim duszpasterzom we Francji przyznano prawo prowadzenia własnych ksiąg parafialnych (chrztów, ślubów i pogrzebów), których kopie corocznie byłyby przekazywane władzom Polskiej Misji Katolickiej. Prymas Polski argumentował, iż po powrocie do Polski kolejnego pokolenia

${ }^{50} \mathrm{CNAEF}$, Julien, Observation sur le projet de règlement redigé par Mgr. Chaptal au sujet des relations à établir entre les aumôniers polonais et le clergé français, Arras, 8 II 1925; Chollet, Observation de Cambrai sur le Projet de Règlement Polonais, Cambrai, 21 II 1925. 
Polaków we Francji, w razie konieczności uzyskania odpisu z księgi sakramentalnej o wiele prościej będzie im zwracać się z prośbą do Rektora Polskiej Misji niż do proboszcza francuskiego czy władz diecezji francuskiej. Nalegał, by umożliwiono prawo do katechizacji w j. polskim i rozszerzono dla dzieci do 14 r. życia. Popierał ideę utworzenia niższego seminarium z zastrzeżeniem, aby uczniom umożliwiono wyjazd wakacyjny do rodzin w Polsce celem zapoznania się $\mathrm{z}$ rodzimymi tradycjami i polską mentalnością ${ }^{51}$. $\mathrm{Z}$ pewnością kard. Dalborowi przed wysłaniem własnych uwag zależało na zapoznaniu się z propozycjami zgłaszanymi przez biskupów francuskich, by móc się do nich również odnieść i mieć decydujący wpływ na ostateczny kształt „Regulaminu”. To też mogło być powodem zwłoki polskiego kardynała z przesłaniem uwag co do jego treści.

$\mathrm{Na}$ podstawie dokumentów z Narodowego Centrum Archiwów Kościoła we Francji można stwierdzić, iż o ile prace nad „Regulaminem dla kapelanów polskich" rozpoczęły się w 1924 r., to obowiązująca wersja została ustalona nie wcześniej niż w marcu $1925 \mathrm{r}$. Na wspominanym już zebraniu 16 grudnia 1924 r. w siedzibie biskupów francuskich przedstawiono jedynie propozycje, które miały służyć za podstawę do dyskusji na temat planowanego dokumentu. Pozostawienie na jego okładce daty „1924 rok” miało świadczyć, iż ostateczna wersja była owocem negocjacji między przedstawicielami Kościoła we Francji i Polsce. Śledząc jednak, na podstawie dokumentów złożonych w archiwum w Paryżu, proces powstawania regulaminu, decyzja o jego ostatecznym kształcie należała do bpa Chaptala. Postanowił on uwzględnić poprawki zgłoszone przez biskupów z Arras i Cambrai ${ }^{52}$. W tym świetle należy rozumieć propozycję polskich księży, którzy niezadowoleni z rozwoju sytuacji zainicjowali, lecz bezowocnie, zimą 1925 r. działania mające na celu wyjednanie w Watykanie dla Polskiej Misji Katolickiej godności Delegatury Apostolskiej ${ }^{53}$. „Regulamin” został wysłany do wszystkich diecezji we Francji, jednak nie wszędzie jego postanowienia zostały wcielone w życie. Jeszcze w 1927 r. kard. A. Hlond w liście do arcybiskupa Paryża ubolewał, iż nie wszędzie jego postanowienia zostały wprowadzone w życie, o czym świadczyły skargi zarówno polskich kapelanów, jak i polskich towarzystw na francuskich proboszczów utrudniających przygotowanie dzieci

\footnotetext{
${ }^{51}$ CNAEF, Dalbor do Chaptala, Poznań, 20 III 1925.

${ }^{52}$ To w wyniku ich interwencji w wersji ostatecznej dodano, nieuwzględnione w wersji zaproponowanej przez bpa Chaptala, punkty „Juridiction (pkt 2)”, „Enseignement du catéchisme (pkt 5)”, ,Denier du Culte (pkt 13)” oraz „Rapport annuel (pkt 14)”.

${ }^{53}$ R. Dzwonkowski, Polska opieka religijna..., s. 60.
} 
polskich do Pierwszej Komunii świętej, a także nauczania katechizmu ${ }^{54}$. Jak wynika z dokumentów przechowywanych w paryskim archiwum, obowiązywał on z pewnością w diecezji paryskiej, Cambrai, Arras, Albi i Metz, Rouen i Meaux, Versailles, Beauvais. Brakuje natomiast informacji o tym, czy jego zasady obowiązywały w diecezjach Lille (obejmująca część dep. Nord) i Nancy et de Toul (dep. Meurthe-et-Moselle) zamieszkiwanych przez wielotysięczną ludność polską ${ }^{55}$.

Kulisy podpisania „Regulaminu” pozwalają zrozumieć, że biskupom francuskim zależało na podporządkowaniu sobie władz Misji Polskiej. Dla bpa Chaptala ważne było, aby katoliccy robotnicy cudzoziemscy nie zważając na braki językowe czy różnice kulturowe zwracali się o pomoc do proboszczów francuskich. Brak kontaktu z francuskimi kapłanami spowodowany nieufnością lub strachem, nie mógł być tolerowany, gdyż księża obcokrajowcy nie będą w stanie zastąpić duchowieństwa miejscowego ${ }^{56}$. W liście do ministra Raymonda Poincaré'a ${ }^{57}$ z 1923 r. bp Chaptal pisał o cudzoziemcach: „Organizacja religijna kontrolowana przez Francuzów, ale mówiąca ich językami (tymi imigrantów) będzie najlepszym sposobem ich asymilacji" ${ }^{\text {"58 }}$. Natomiast w artykule wydrukowanym 13 grudnia 1924 r. (czyli trzy dni przed spotkaniem z księżmi polskimi w arcybiskupstwie paryskim) w czasopiśmie „La vie catholique" stwierdził, iż czynnikiem decydującym i podtrzymującym odrębną tożsamość religijną polskiego wychodźstwa byli przybywający z nim do Francji księża ${ }^{59}$, dając tym samym do zrozumienia, iż stanowili oni przeszkodę do pełnej integracji wszystkich wiernych w diecezji. Dostrzegał jednak pozytywną rolę tychże duchownych w walce $\mathrm{z}$ komunizmem i sektami.

Kulisy podpisania „Regulaminu” pozwalają bliżej poznać relacje panujące pomiędzy biskupami francuskimi. We Francji aż do 1964 r. nie istniał organ kolegialny, którego członkami byliby wszyscy biskupi. Nie było, tak jak w Polsce, jednego przywódcy hierarchii kościelnej, który by sprawował

\footnotetext{
${ }^{54}$ CNAEF, Hlond do Dubois, Poznań, 24 VIII 1927.

${ }^{55}$ J. GRUSZYŃSKI, Społeczność polska we Francji 1918-1978, Warszawa 1981, s. 64-65; H. JANOwSKA, Polska emigracja zarobkowa we Francji 1919-1939, Warszawa 1964, s. 122-123; J. PONTY, Polonais méconnus. Histoire des travailleurs immigrés en France dans l'entre-deux-guerres, Paris 2005, s.125-129.

${ }^{56}$ AHP, Oeuvres pour les étrangers, sygn. 9 K 2 11, Chaptal, Projet de manuel pour les travailleurs catholique étrangers en France, [b.d.].

${ }^{57}$ Raymond Poincaré (1860-1934) - prezydent Republiki (1913-1920), minister spraw zagranicznych (1922-1924).

${ }^{58}$ R. SCHOR, Le facteur religieux et l'intégration des étrangers en France 1919-1939, „Vingtième Siècle” 7 (1985), s. 110.

59 J.L. Clement, Mgr Chaptal et la Mission diocésaine des étrangers, „Migration et religion en France" 78 (2008), s. 55.
} 
funkcję nadrzędną wobec pozostałych biskupów ${ }^{60}$. Kardynał Dubois, jako arcybiskup Paryża, cieszył się jedynie uznaniem moralnym. Przewodniczącym istniejącego w latach 1919-1964 Zgromadzenia Kardynałów i Arcybiskupów Francji (ACA) był najstarszy z kardynałów (do 1930 r.) - kard. Louis Luçon $^{61} \mathrm{z}$ Reims, zaś ważną rolę odgrywał również sekretarz Komisji Stałej, abp Chollet z Cambrai (1952). Tak więc, o ile diecezja paryska w sprawach organizacji duszpasterstwa cudzoziemców odgrywała rolę inicjującą i modelową ${ }^{62}$, to jednak implantacja decyzji podjętych w Paryżu przez biskupów z prowincji zależała wyłącznie od dobrej ich woli ${ }^{63}$. Również Zgromadzenie Kardynałów i Arcybiskupów nie dysponowało narzędziami mogącymi zmusić pozostałych ordynariuszy do zaakceptowania decyzji, zwłaszcza że ci ostatni, jak wynika z korespondencji z kard. Dubois, często podkreślali swoją autonomię. Pomimo niedoskonałości, zasady zawarte $\mathrm{w}$ „Regulaminie dla księży polskich" pozwalały zabezpieczyć organizację duszpasterstwa polskiego we Francji i do 1952 r. (ogłoszenie konstytucji Exsul Familia Piusa XII) stanowił on podstawę prawną działalności polskich księży w tym kraju.

\section{Załącznik}

Règlement des aumôniers polonais, établi entre le Cardinal Dubois Archevêque de Paris, assisté de Mgr Chollet et entre l'Episcopat Polonais, représenté par le Recteur de la Mission Polonaise Catholique, le Rév. Père Szymbor Guillaume (1924) ${ }^{64}$,

Archiwum Kościoła i Hospicjum Świętego Stanisława w Rzymie, Archiwum biskupa Józefa Gawliny, sygn. AJG 1:

$1^{\circ}$ - Logement des aumôniers

Les aumôniers résidents devraient être logés soit par les administrations qui les ont fait venir, soit par MM. les Curés dans la paroisse desquels ils viennent s'établir. Il ne

\footnotetext{
${ }^{60}$ We Francji kilku biskupów nosiło tytuł prymasa: w Lyonie - Prymas Galii, w Rouen - Prymas Normandii, Rennes - Prymas Bretanii. Prawo do tytułu prymasa rościli sobie rządcy diecezji w Akwitanii, Bourges i Bordeaux, Dictionnaire..., s. 810.

${ }^{61}$ Louis Luçon (1842-1930) - biskup Belley (1887), arcybiskup Reims (1906), kardynał (1907), Dictionnaire..., s. 428-429.

${ }^{62} \mathrm{R}$. SCHOR, Une solidarité religieuse: l'accueil des catholiques étrangers par l'Eglise en France (1919-1939), „Cahiers de la Méditerranée” (hors série) 6 (1982), s. 138.

${ }^{63}$ J.-M. MAYEUR, Les documents collectifs de l'épiscopat français relatifs aux questions temporelles de 1944-1962, [w:] Forces religieuses et attitudes politiques dans la France contemporaine, red. R. Rémond, Paris 1965 , s. 355-356.

${ }^{64}$ Drukiem wytłuszczonym dodano fragmenty, o które został uzupełniony „Règlement proposé par S.G. Mgr Chaptal” i które znalazły się w ostatecznej wersji dokumentu. Zaznaczano również słowa wykreślone z projektu dokumentu.
} 
serait pas convenable qu'ils fussent obligés de descendre à l'hôtel, et encore moins dans les maisons particulières habitées par les familles polonaises. Les aumôniers qui passent dans les paroisses avec une mission temporaire devraient également être logés par l'administration diocésaine ou par l'organisation agricole ou autre, qui les fait venir.

\section{$2^{\circ}-\underline{\text { Juridiction }}$}

Les aumôniers ne sont pas curés et n'ont pas la juridiction attachée à ce titre. Dans la paroisse où ils résident, ils seront, au point de vue juridiction, considérés comme vicaires coopérateurs. Dans les paroisses où ils sont chargés par l'Ordinaire d'exercer leur ministère mais où ils ne résident pas, ils seront regardés comme prêtres auxiliaires chargés du service religieux des Polonais (offices religieux, administration des sacrements, catéchisme), mais sans délégation générale.

$3^{\circ}$ - Heure des offices et des cérémonies religieuses demandées par les familles

Il est de l'intérêt des fidèles polonais et des fidèles français que les offices polonais aient lieu à des heures déterminées d'avance d'un commun accord entre MM. les Curés et MM. les Aumôniers, de manière que ces offices puissent se célébrer avec toute la dignité nécessaire. Ils auront toujours lieu à l'heure exacte qui a été annoncée et ils ne seront pas prolongés d'une manière excessive. Sauf dans les cas où les Polonais auraient la jouissance d'une chapelle particulière, l'aumônier préviendra par écrit le curé, des baptêmes, mariages, services funèbres, qui doivent se célébrer dans les églises paroissiales. Il donnera des indications de nom propre et de domicile.

$4^{\circ}$ - Baptêmes

Il serait bon que les Aumôniers polonais, quand ils sont résidents, fussent appelés, autant qu'il sera possible, pour baptiser les enfants polonais, dans la région voisine de leur résidence. Ces enfants seraient toujours inserits sur les régistres paroissiaux. Les prêtres polonais, appelés à faire un baptême, doivent, aussitôt la cérémonie terminée, inscrire sur le registre paroissial l'acte de baptême et faire signer le parrain et la marraine. Ils peuvent tenir pour leur usage personnel un registre supplémentaire facultatif.

\section{$5^{\circ}$ - Enseignement du catéchisme}

Tous les enfants polonais de $\mathbf{7}$ à $\mathbf{1 3}$ ans sont tenus de suivre l'enseignement du catéchisme qui leur sera donné par les Aumôniers polonais ou par les instituteurs polonais ayant la mission canonique de $M$. le Recteur. La durée du catéchisme préparatoire à la première communion sera de deux ans, sauf en cas d'impossibilité.

Dans les localités où les aumôniers polonais ou les instituteurs ne peuvent l'assurer, le catéchisme sera fait par le clergé local.

\section{$6^{\circ}$ - Première communion}

La première communion étant une cérémonie qui doit laisser dans l'esprit des parents et des enfants un souvenir durable et profond, il est à souhaiter que les premières communions solennelles des enfants polonais aient lieu séparément et que les Aumôniers polonais puissent donner eux-mêmes à leurs enfants des instructions et faire chanter des cantiques polonais. C'est la pratique habituelle des colonies françaises à l'étranger de 
faire faire par des Aumôniers français la première communion de leurs enfants. Il est nécessaire que pour les conditions d'admission à la première communion solennelle (âge, fréquentation du catéchisme et des offices, examen préalable), les enfants polonais soient soumis au même règlement que les enfants français. Les dispenses sont réservées à l'Evêché.

\section{$7^{\circ}$ - Saluts du Saint Sacrement et messes polonaises}

On a souvent reproché aux Aumôniers de faire chanter des chants en langue polonaise pendant le salut du Saint Sacrement et même à la place du Tantum Ergo, ainsi que pendant la liturgie de la Gd;-Messe. Une réponse de la S. C. des Rites aux Evêques du Brésil a reconnu en ceci un privilège pour les Aumôniers polonais.

\section{$8^{\circ}-\underline{\text { Mariages }}$}

Pour assurer la validité des mariages et pour satisfaire aux légitimes besoins religieux de la population polonaise, ilest utile que l'Aumônier polonais ait une délégation générale. Il aura cette délégation s'illest nommé coopérateur du Curé de la paroisse dans łaquelle il réside, l'Aumônier polonais sera nommé coopérateur du Curé de la paroisse dans laquelle il réside. Il devra se faire déléguer pour chacun des mariages qu'il bénira dans les autres paroisses (Can. 1096, 1). Quant aux bans de mariages, s'il s'agit d'un mariage entre Français et Polonais, ou si les futurs résident tous les deux dans une paroisse où il n'y a pas d'offices polonais hebdomadaires, on suivra la règle commune. Si les futurs sont tous deux Polonais et résident dans une paroisse où se célèbre chaque dimanche un office polonais, il suffira que les bans soient proclamés à cet office. Les dispenses de bans sont réservées à l'Ordinaire.

$9^{\circ}-\underline{\text { Registres }}$

Il est nécessaire que les baptêmes, les mariages et les enterrements soient enregistrés dans les paroisses où ils ont lieu. Les mariage pourront être inscrits sur un registe spécial par l'Aumônier polonais, mais un double de ce registre doit toujours être remis à l'Evêché à la fin de l'année. Cette inscription doit se faire sur le registre paroissial aussitôt après la cérémonie. L'Aumônier polonais tiendra un second registre particulier en langue polonaise, et ce registre devra être remis chaque année à la Mission Catholique Polonaise à Paris.

$10^{\circ}-\underline{\text { Droits }}$

Les droits afférents à la célébration des mariages et des enterrements seront attribués à l'Aumônier polonais, suivant les tarifs établis pour les vicaires coopérateurs. Le tarif diocésain en vigueur pour les mariages et les funérailles est communiqué par le Curé aux intéressés.

Pour les mariages et les funérailles, à moins de conventions spéciales approuvées par l'Evêché, les Aumôniers doivent remettre au Curé de la paroisse les autres droits prévus par le tarif diocésain (part de la fabrique, des employés d'église, du Curé). Les oblations volontaires faites à l'occasion des baptêmes appartiennent au prêtre polonais s'il a administré lui-même le Sacrement. Les offrandes proprement dites faites à l'Offertoire de la Messe appartiennent au Curé de la paroisse. 
$11^{\circ}$ - Confessionnaux

Dans les églises où les Polonais ont l'habitude de se présenter pour recevoir le Sacrement de Pénitence, il serait bon qu'un des confessionnaux fût habituellement affecté à l'Aumônier polonais et portât en polonais cette inscription: «Confesseur polonais ». Quand il n'y a qu'un confessionnal, le prêtre polonais pourrait y confesser à des heures déterminées au préalable avec le Curé.

$12^{\circ}$ - Cérémonies religieuses

Pour les cérémonies religieuses que font célébrer les Aumôniers polonais dans les églises françaises, une seule quête sera établie et, à moins de conventions spéciales approuvées par l'Evêché, elle sera également partagée entre le Curé pour les frais du eulte-et l'Aumônier. La quête sera toujours remise à la Sacristie après l'Office. Lorsqu'il y aura des quêtes impérées, tout le produit de la collecte sera remis à l'Evêché.

$13^{\circ}$ - Denier du Culte

MM. les Aumôniers organiseront chaque année la quête du Denier du Culte à domicile et en verseront le produit à l'Evêché.

$14^{\circ}$ - Rapport annuel

Un rapport annuel sera présenté par chacun des Aumôniers polonais à l'Evêché. Il rendra compte des résultats obtenus, des difficultés rencontrées et des progrès qui restent à réaliser.

\section{BIBLIOGRAFIA}

\section{Źródla archiwalne}

Le Centre national des archives de l'Église de France [CNAEF]

Service national pour la pastorale des migrants, sygn. $121 \mathrm{CO} 1$

Archives historiques du diocèse de Paris [AHP]

Polonais, sygn. 9 K 23

Oeuvres pour les étrangers, sygn. $9 \mathrm{~K} 211$

Louis-Ernest Dubois, sygn. 1D 12,14

Archiwum Kościoła i Hospicjum Świętego Stanisława w Rzymie

Archiwum biskupa Józefa Gawliny, sygn. AJG 1

Opracowania, publikacje źródłowe i słowniki

BaKalarz J., Duszpasterstwo polonijne, [w:] Encyklopedia Katolicka, t. V, Lublin: TN KUL 1989, kol. 616-618.

Brudzisz M., Archiwum Polskiej Misji Katolickiej we Francji, Kraków-Lublin: Homo Dei 2015.

Brudzisz M., Pierwsze zebranie księży Polskiej Misji Katolickiej we Francji, „Studia Polonijne” 33 (2012), s. 141-154. 
Clement J.L., Mgr Chaptal et la Mission diocésaine des étrangers, „Migration et religion en France" 78 (2008), s. 53-63.

Dictionnaire des évêques de France au XXe siècle, red. D.M. Dauzet, F. Le Moigne, Paris: Cerf 2010.

Dzwonkowski R., Polska opieka religijna we Francji 1909-1939, Poznań-Warszawa: Pallottinum 1988.

GARÇON G., Les catholiques polonais en France (1919-1949), Lille: Rayonnement culturel polonais 2004.

GRUSZYŃSKI J., Społeczność polska we Francji 1918-1978, Warszawa: PWN 1981.

GRUSZYŃSKi J., Integracja religijna Polaków we Francji, „Studia Polonijne” 4 (1981), s. 159-176.

JANOWSKA H., Polska emigracja zarobkowa we Francji 1919-1939, Warszawa: Książka i Wiedza 1964.

KLAKus M., Visite des évêques français en Pologne en 1924 à la lumière de dossier déposé par le Cardinal Dubois dans les archives historiques du diocèse de Paris, „Archiwa, Biblioteki i Muzea Kościelne” 2020, t. 113, s. 221-235.

KoŁodZiEj B., Biskup polscy w trosce o polskich emigrantów, „Studia Prymasowskie” 2 (2008), s. 201-218.

MAYeur J.-M., Les documents collectifs de l'épiscopat français relatifs aux questions temporelles de 1944-1962, [w:] Forces religieuses et attitudes politiques dans la France contemporaine, red. R. Rémond, Paris: Académique 1965, s. 351-376.

PANEK B., Księża polscy w duszpasterstwie północnej Francji 1922-1929 (Materiały do dziejów Polskiej Misji Katolickiej we Francji, cz. 1-2, z. 4), Paris: Editions François-Dominique 1994.

PonTy J., Polonais méconnus. Histoire des travailleurs immigrés en France dans l'entre-deuxguerres, Paris: Publications de la Sorbonne 2005.

SCHOR R., Le facteur religieux et l'intégration des étrangers en France 1919-1939, „Vingtième Siècle" 7 (1985), s. 103-116.

SCHOR R., Une solidarité religieuse: l'accueil des catholiques étrangers par l'Eglise en France (1919-1939), „Cahiers de la Méditerranée” 6 (1982), s. 135-146.

SZYMAŃSKi J., „Nie chcemy tego ukrywać” - oczami świadków. Sytuacja duszpasterstwa polonijnego w północnej Francji w 1928 roku, „Archiwa, Biblioteki i Muzea Kościelne” 2012, t. 98, s. 407-417.

ŻABA K.M., Charakter życia religijnego Polonii a status prawny polonijnych instytucji religijnych we Francji, „Przegląd Polonijny” 13 (1987), nr 1, s. 49-65.

\section{„REGULAMIN DLA KAPELANÓW POLSKICH” WE FRANCJI - OKOLICZNOŚCI POWSTANIA}

Streszczenie

Po zakończeniu pierwszej wojny światowej rozpoczęła się nowa fala polskiej emigracji zarobkowej we Francji. Do 1921 r. w tym kraju osiedliło się ponad 45 tysięcy Polaków. W 1922 r. władze kościelne dokonały reorganizacji Misji Polskiej w Paryżu, nadając jej charakter delegatury Prymasa Polski. Podstawowym dokumentem zawierającym normy, wedle których winna być zorganizowana opieka duszpasterska nad polskimi wychodźcami (sposób udzielania sakramen- 
tów, organizacja katechizacji, sprawowanie pogrzebów, prowadzenie ksiąg parafialnych), jak i poruszającym sprawy dotyczące zabezpieczenia materialnego polskich kapelanów (zamieszkanie, opłaty i zbiórki wśród wiernych na cele związane z prowadzeniem duszpasterstwa), był ustalony w 1925 r. „Regulamin dla kapelanów polskich” we Francji. W dokumencie tym starano się również uregulować stosunek do miejscowych biskupów i francuskich proboszczów (raporty, ofiary na rzecz diecezji i parafii, godziny korzystania z miejscowego kościoła). Za jego redakcję odpowiadał odpowiedzialny za sprawy organizacji duszpasterstwa obcokrajowców w Paryżu bp Emmanuel Chaptal. Pomimo iż w pierwotnej wersji z grudnia 1924 r. uwzględnił on propozycje zgłaszane przez księży polskich pracujących we Francji, to ostateczny wpływ na jego kształt miały poprawki zgłoszone przez biskupów z Arras i Cambrai.

Słowa kluczowe: Regulamin; kapelani; misja polska; Szymbor; Chaptal; Polacy we Francji

\section{„REGULATIONS FOR POLISH CHAPLAINS” IN FRANCE - CIRCUMSTANCES OF THE UPRISING}

\section{Summary}

After the end of World War I, a new wave of Polish economic emigration in France began. By 1921, over 45 thousand Polish had settled in this country. In 1922, the church authorities reorganized the Polish Mission in Paris, giving it the character of a delegation of the Polish Primate. The basic document containing the norms according to which the pastoral care of the Polish immigrants should be organized (the way of administering the sacraments, the organization of catechization, holding funerals, keeping parish books), as well as the issues concerning the material security of Polish chaplains (residence, fees and collections among the faithful for the purposes of pastoral care) was established in 1925 „Regulations for Polish Chaplains” in France. The document also sought to regulate attitudes towards local bishops and French pastors (reports, sacrifices to dioceses and parishes, hours of use of the local church). It was in charge of its editorial office, responsible for the organisation of the pastoral care of foreigners in Paris Emmanuel Chaptal. Although in its original version of December 1924 it took into account the proposals made by Polish priests working in France, the final shape was influenced by the amendments made by the bishops of Arras and Cambrai.

Keywords: Regulations; chaplains; Polish Mission; Szymbor; Chaptal; Polish in France 